\title{
THE EFFECT OF TRIETHYLTIN ON OXIDATIVE PHOSPHORYLATION AND MITOCHONDRIAL ADENOSINE TRIPHOSPHATASE ACTIVATION
}

\author{
K. E. MOORE* and T. M. BRODY \\ Department of Pharmacology, \\ University of Michigan Medical School, Ann Arbor, Michigan
}

(Received 22 July 1960)

\begin{abstract}
Triethyltin inhibits the respiration of rat brain slices following in vitro and in vivo administration. When added in vitro this alkyltin compound uncouples oxidative phosphorylation of rat brain and liver homogenates and mitochondria. Triethyltin also inhibits both the magnesium and the 2:4-dinitrophenol activated adenosine triphosphatases of isolated rat liver mitchondria.
\end{abstract}

ALKYLTIN compounds are extremely toxic materials. ${ }^{1}$ Their indiscriminate use in France for the treatment of furunculosis resulted in the unfortunate death of over one hundred persons. ${ }^{2}$ During the course of our study on the toxicity of triethyltin acetate we observed that this compound had many interesting biochemical properties. We have confirmed the work of Aldridge and Cremer $^{3}$ and of Aldridge ${ }^{4}$ that this compound inhibits brain slice respiration and is capable of uncoupling oxidative phosphorylation at concentrations comparable to those that are found in tissues after this agent is injected into rats. In contrast to the work of Aldridge ${ }^{4}$ we have found that triethyltin (TET) is incapable of accelerating the rate of oxidation of acceptor-deficient mitochondrial systems and inhibits both the latent or magnesium-activated adenosine triphosphatase and the dinitrophenol-activated adenosine triphosphatase. The significance of these findings relative to the toxicity of this compound and its use as a biochemical research tool will be considered in the present communication.

\section{EXPERIMENTAL MATERIALS AND METHODS}

Female rats (Sprague-Dawley) weighing approximately $200 \mathrm{~g}$ were used in this study. All preparative procedures were carried out in a $5{ }^{\circ} \mathrm{C}$ cold room. The animals were sacrificed by decapitation and slices were prepared from liver and cerebral cortex by the method of Deutsch. ${ }^{5}$ Two slices (total weight approximately $100 \mathrm{mg}$ ) were weighed and placed in Warburg vessels containing $1.27 \times 10^{-1} \mathrm{M} \mathrm{NaCl}, 5 \cdot 1 \times 10^{-3} \mathrm{M}$ $\mathrm{KCl}, 1.27 \times 10^{-3} \mathrm{KH}_{2} \mathrm{PO}_{4}, 1 \times 10^{-2} \mathrm{M} \mathrm{Na}_{2} \mathrm{HPO}_{4} \mathrm{pH} 7.4,1.36 \times 10^{-3} \mathrm{M} \mathrm{CaCl}_{2}$, $1.27 \times 10^{-3} \mathrm{M} \mathrm{MgSO}_{4}$ and $1.1 \times 10^{-2} \mathrm{M}$ glucose. The total volume was $2.0 \mathrm{ml}$ and the center well contained $0.2 \mathrm{ml} 2 \mathrm{~N} \mathrm{KOH}$ with filter paper. The gas phase was oxygen and the temperature $37^{\circ} \mathrm{C}$. After an equilibration of $10 \mathrm{~min}$ the oxygen consumption was determined for a $30-\mathrm{min}$ period.

* Present address; Department of Pharmacology, Dartmouth Medical School, Hanover, N.H. 
Oxidative phosphorylation was performed on brain and liver homogenates and mitchondria by the method of Brody and Bain. ${ }^{6}$ Twenty per cent homogenates of liver and brain were prepared by the method of Potter and Elvehjem. ${ }^{7}$ Liver mitochondria were isolated according to the procedures described by Hogeboom et al. ${ }^{8}$ so that the final concentration contained mitchondria from $500 \mathrm{mg}$ wet weight liver per ml. Brain mitochondria were prepared as described by Brody and Bain ${ }^{9}$ so that 1 $\mathrm{ml}$ of the final concentration contained the mitochondria from $1 \mathrm{~g}$ of brain. Each Warburg vessel contained $2.5 \times 10^{-2} \mathrm{M}$ potassium phosphate buffer $\mathrm{pH} 7.4$. $1.1 \times 10^{-2} \mathrm{M}$ glycylglycine buffer $\mathrm{pH} 7 \cdot 4,1.2 \times 10^{-2} \mathrm{M} \mathrm{KCl}, 1.25 \times 10^{-2} \mathrm{M} \mathrm{MgCl}_{2}$. $2.8 \times 10^{-3} \mathrm{M}$ dipotassium adenosine triphosphate (ATP), $1.0 \times 10^{-5} \mathrm{M}$ cytochrome $c$, 25 units yeast hexokinase (Pabst), $3.3 \times 10^{-2} \mathrm{M}$ glucose, $0.4 \mathrm{ml}$ mitochondrial suspension or homogenate and $1.5 \times 10^{-2} \mathrm{M} \mathrm{NaF}$. Substrate concentrations are given in the individual tables. The total volume of the reaction mixture was $1.9 \mathrm{ml}$ while the side arm contained $0.1 \mathrm{ml} 75$ per cent trichloroacetic acid and the center well $0.2 \mathrm{ml}$ $2 \mathrm{~N} \mathrm{KOH}$. The temperature was $30^{\circ} \mathrm{C}$ and the gas phase was air. After temperature equilibration of the flasks for 9 min they were incubated for a pcriod of $10 \mathrm{~min}$.

The 2:4-dinitrophenol activated adenosine triophosphatase (DNP ATPase) was determined in individual test tubes containing $5 \times 10^{-2} \mathrm{M}$ Tris buffer at various $\mathrm{pH}$ values, $2.5 \times 10^{-2} \mathrm{M} \mathrm{KCl}, 1.47 \times 10^{-1} \mathrm{M}$ sucrose, $1 \times 10^{-3} \mathrm{M}$ disodium ethylenediaminetetra-acetic acid (EDTA), $1 \times 10^{-4} \mathrm{M} \mathrm{2:4-dinitrophenol} \mathrm{(DNP)} \mathrm{and} \mathrm{mito-}$ chondria equivalent to $50 \mathrm{mg}$ liver. For the magnesium-activated adenosine triphosphatase (Mg ATPase) the conditions were the same except that the DNP and EDTA were omitted and instead the tubes contained $5 \times 10^{-3} \mathrm{M} \mathrm{MgCl}_{2}$. After thermal equilibration, ATP (final concentration $2.5 \times 10^{-3} \mathrm{M}$ ) was added to the tubes so that

\section{TABLE 1. EFFECT OF in vitro TRIETHYLTIN ON BRAIN SLICE RESPIRATION}

\begin{tabular}{l|c|c|c}
\hline \multicolumn{1}{c|}{ Additions } & Number of expts. & $Q_{0_{2}{ }^{*}}$ & $\%$ of control \\
\hline Control & 17 & $76 \cdot 0 \pm 9 \cdot 2$ & 100 \\
TET $10^{-7} \mathrm{M}$ & 11 & $82 \cdot 2 \pm 10 \cdot 0$ & 108 \\
TET $10^{-6} \mathrm{M}$ & 12 & $56 \cdot 3 \pm 7 \cdot 9$ & $72 \cdot 7 \dagger$ \\
TET $10^{-5} \mathrm{M}$ & 8 & $29 \cdot 2 \pm 8 \cdot 3$ & $38 \cdot 4 \dagger$ \\
TET $10^{-4} \mathrm{M}$ & 4 & $10 \cdot 9 \pm 2 \cdot 6$ & $14 \cdot 4 \dagger$ \\
\hline
\end{tabular}

$*$ Mean \pm standard deviation $=\mu \mathrm{M}_{\mathrm{O}_{2}} / \mathrm{g}$ wet weight $/ \mathrm{hr}$. level.

$\dagger$ Significantly different from control at less than 1 per cent confidence

the final reaction volume was $1.8 \mathrm{ml}$. The reaction was stopped at zero and $15 \mathrm{~min}$ by the addition of $0.2 \mathrm{ml}$ of 50 per cent trichloroacetic acid. All experiments were performed at $30^{\circ} \mathrm{C}$. Inorganic phosphate was determined by the method of Fiske and SubbaRow. ${ }^{10}$

\section{RESULTS}

\section{Tissue slice respiration}

Initial studies with TET were performed on brain slices since Aldridge and Cremer $^{3,11}$ reported that the organo-tin compounds were potent inhibitors of brain but not liver slices. As seen in Table 1 TET significantly reduces the respiration of rat 
brain slices at concentrations as low as $10^{-6} \mathrm{M}$. This inhibitory action was more pronounced as the concentration of TET increased.

Confirming the results of Cremer ${ }^{11}$ it was found that liver slices were not profoundly inhibited by the in vitro actions of TET. In three determinations at $10^{-4} \mathrm{M}$ TET the liver slice respiration was reduced by 23,30 and 36 per cent and at $10^{-5} \mathrm{M}$ TET by only 9,10 and 7 per cent. When compared with a reduction of respiration in brain slices of 85 per cent at $10^{-4} \mathrm{M}$ and 60 per cent at $10^{-5} \mathrm{M}$ TET (Table 1) it is evident that the brain is somewhat more sensitive to the inhibitory actions of TET.

Following injection of triethyltin acetate $(10 \mathrm{mg} / \mathrm{kg})$ into rats a decrease in brain but not in liver slice respiration of treated animals was observed (Table 2). In all but

Table 2. EFFECT OF in vivo TRIETHYLTIN ON BRAIN AND LIVER SLICE RESPIRATION

\begin{tabular}{|c|c|c|c|}
\hline \multirow{2}{*}{$\begin{array}{l}\text { Hours after } \\
\text { injection }\end{array}$} & & \multicolumn{2}{|c|}{ Mean $\%$ of control $\mathrm{O}_{2}$ uptake } \\
\hline & Route & Brain & Liver \\
\hline $\begin{array}{l}2 \\
2 \\
2 \\
2 \\
2 \\
4 \\
6 \\
2 \\
4 \\
6\end{array}$ & $\begin{array}{l}\text { i.p. } \\
\text { i.p. } \\
\text { i.p. } \\
\text { i.p. } \\
\text { i.p. } \\
\text { i.p. } \\
\text { i.p. } \\
\text { s.q. } \\
\text { s.q. } \\
\text { s.q. }\end{array}$ & $\begin{aligned} * 63 & (40-78) \\
87 & (82-91) \\
103 & (93-117) \\
74 & (69-80) \\
85 & (74-100) \\
83 & (76-89) \\
77 & (59-86) \\
96 & (95-98) \\
99 & (93-107) \\
72 & (66-79)\end{aligned}$ & $\begin{array}{r}103(\overline{98-114)} \\
101(93-110) \\
119(102-142) \\
115(100-138) \\
106(89-117) \\
94(\overline{70-124)} \\
101(\overline{86-112)} \\
108(99-116)\end{array}$ \\
\hline
\end{tabular}

* Figures represent the mean and range of the percentage of the $Q_{\mathrm{O}_{2}}$ of slices removed from rats receiving $10 \mathrm{mg} / \mathrm{kg}$ triethyltin acetate when compared with the $Q_{\mathrm{O}_{2}}$ of slices removed from control animals. Each mean represents the percentage calculated from two flasks containing control slices and four flasks containing treated slices. i.p. = intraperitoneal and s.q. $=$ subcutaneous route of injection.

one experiment the brain slice respiration was decreased while that of the liver slices was often slightly increased $2 \mathrm{hr}$ after intraperitoneal injection. By the subcutaneous route a longer time after injection $(6 \mathrm{hr})$ was required before inhibition could be detected. This was probably due to the time required for the concentration of TET in the brain to reach adequate levels. That brain slice respiration was more selectively sensitive to TET was also indicated by TET tissue distribution studies. Analyses of tissues for TET $2 \mathrm{hr}$ after injection revealed from 5 to 10 times as much TET in the liver as in the brain (Moore and Brody, unpublished), yet liver slice respiration was not depressed. This finding has also been reported by other investigators. ${ }^{11}$

\section{Homogenate and mitochondrial oxidative phosphorylation}

Although brain slices appeared to be much more sensitive than liver slices to the inhibitory actions of TET, mitochondria and homogenates from both brain and liver were equally affected by TET in vitro. As seen in Table 3 the respiration of both brain and liver homogenates was markedly inhibited by $10^{-5} \mathrm{M}$ TET. Glutamate oxidation appeared to be more sensitive to the actions of this compound than did the succinoxidase system since at $10^{-4} \mathrm{M}$ TET, glutamate oxidation was reduced by $80-90$ per cent 
whereas succinate oxidation was reduced by only $30-50$ per cent. Although this difference occurred between these two systems with respect to respiration, the phosphorylating ability with both substrates was equally depressed. In the isolated mitochondrial preparations the inhibition of respiration and uncoupling of oxidative phosphorylation was similar to that observed in the homogenate preparations.

TABLE 3. EFFECT OF in vitro TRIETHYLTIN ON OXIDATIVE PHOSPHORYLATION

\begin{tabular}{|c|c|c|c|c|c|c|c|}
\hline \multirow{2}{*}{ Preparation } & \multirow{2}{*}{ Substrate } & & \multicolumn{5}{|c|}{ Triethyltin concentration } \\
\hline & & & None & $10^{-6} \mathrm{M}$ & $10^{-5} \mathrm{M}$ & $5 \therefore 10^{-5} \mathrm{M}$ & $10^{-4} \mathrm{M}$ \\
\hline \multirow{2}{*}{ Brain homogenate } & G & $\underset{\mathrm{P} / \mathrm{O}}{Q_{\mathrm{O}_{2}}}$ & $\begin{array}{l}3.76 \\
1.92\end{array}$ & $\begin{array}{l}3 \cdot 38 \\
1 \cdot 43\end{array}$ & $\begin{array}{l}2 \cdot 78 \\
1.26\end{array}$ & $\begin{array}{l}1 \cdot 15 \\
0 \cdot 22\end{array}$ & $\begin{array}{l}0 \cdot 77 \\
0\end{array}$ \\
\hline & $\mathbf{S}$ & $\begin{array}{l}\mathrm{OOg}_{2} \\
\mathbf{P} / \mathrm{O}\end{array}$ & $\begin{array}{l}4 \cdot 63 \\
1 \cdot 10\end{array}$ & $\begin{array}{l}4 \cdot 35 \\
1 \cdot 16\end{array}$ & $\begin{array}{l}4.02 \\
0.93\end{array}$ & $\begin{array}{l}2 \cdot 93 \\
0\end{array}$ & $\begin{array}{l}3.03 \\
0\end{array}$ \\
\hline \multirow{2}{*}{ Liver homogenate } & G & $\underset{\mathbf{P} / \mathbf{O}}{Q_{\mathrm{O}_{2}}}$ & $\begin{array}{l}8.83 \\
1.99\end{array}$ & $\begin{array}{l}8.61 \\
1.95\end{array}$ & $\begin{array}{l}6.32 \\
1.63\end{array}$ & $\begin{array}{l}2.53 \\
0.92\end{array}$ & $\begin{array}{l}0.81 \\
0\end{array}$ \\
\hline & $s$ & $\stackrel{\mathrm{O}_{\mathrm{O}_{2}}}{\mathbf{P} / \mathrm{O}}$ & $\begin{array}{r}10 \cdot 70 \\
1.13\end{array}$ & $\begin{array}{r}10.80 \\
1.21\end{array}$ & $\begin{array}{l}8.90 \\
0.95\end{array}$ & $\begin{array}{l}5 \cdot 40 \\
0 \cdot 30\end{array}$ & $\begin{array}{l}5 \cdot 40 \\
0\end{array}$ \\
\hline \multirow{2}{*}{ Brain mitochondria } & $\mathrm{G}$ & $\frac{\mathrm{QO}_{2}}{\mathrm{P} / \mathrm{O}}$ & $\begin{array}{l}3 \cdot 12 \\
2 \cdot 54\end{array}$ & $\begin{array}{l}3 \cdot 18 \\
2 \cdot 63\end{array}$ & $\begin{array}{l}1.46 \\
1.12\end{array}$ & $\begin{array}{l}0 \cdot 77 \\
0\end{array}$ & - \\
\hline & $\mathbf{s}$ & $\begin{array}{l}Q_{\mathrm{O}_{2}} \\
\mathrm{P} / \mathrm{O}\end{array}$ & $\begin{array}{l}4.69 \\
1.66\end{array}$ & $\begin{array}{l}4 \cdot 49 \\
1 \cdot 16\end{array}$ & $\begin{array}{l}3 \cdot 50 \\
3 \cdot 57\end{array}$ & $\begin{array}{l}3 \cdot 13 \\
0.13\end{array}$ & - \\
\hline \multirow{2}{*}{ Liver mitochondria } & $\mathrm{G}$ & $\underset{\mathbf{P} / \mathrm{O}}{Q_{\mathrm{O}_{2}}}$ & $\begin{array}{l}5.43 \\
2.79\end{array}$ & 二 & $\begin{array}{l}2.46 \\
1.62\end{array}$ & $\begin{array}{l}0 \cdot 10 \\
0\end{array}$ & $\begin{array}{l}0 \cdot 11 \\
0\end{array}$ \\
\hline & $\mathrm{s}$ & $\frac{Q_{\mathrm{O}_{2}}}{\mathrm{P} / \mathrm{O}}$ & $\begin{array}{l}8.07 \\
1.74\end{array}$ & 二 & $\begin{array}{l}8 \cdot 11 \\
1.03\end{array}$ & $\begin{array}{l}5.87 \\
0.20\end{array}$ & 二 \\
\hline
\end{tabular}

$\mathrm{G}=$ glutamate, $\mathrm{S}=$ succinate; both at substrate concentrations of $0.01 \mathrm{M}$.

$Q_{\mathrm{O}_{2}}=$ microatoms of oxygen uptake.

$\mathrm{P} / \mathrm{O}$ - ratio of micromoles phosphate uptake to microatoms of oxygen uptake.

Because of the apparent greater sensitivity of the diphosphopyridine (DPN)-linked dehydrogenase system to the in vitro actions of TET, the effects of DPN addition to there action medium was studied. Table 4 illustrates the ability of DPN partially to restore the oxidative activity of isolated mitochondria. TET markedly depressed oxygen uptake which was restored to approximately half of the control level by the addition of DPN. The apparent loss of this cofactor from the mitochondria, perhaps as a consequence of mitochondrial swelling, may account for the greater inhibition of glutamate oxidation than of succinoxidase activity seen with TET.

In order to determine if the uncoupling action of TET as seen in the in vitro systems could also be demonstrated in the whole animal, homogenates and mitochondria were prepared from brains and livers of rats injected with this compound. Despite the potent uncoupling ability of TET added in vitro we were unable to detect any uncoupling effects in mitochondria and homogenates prepared from brain and liver of TET treated rats. The reason for the failure to see uncoupling in these mitochondria is apparently the result of a decrease in TET concentration during the washing of the mitochondria. In Table 5, preparation of the mitochondria in isotonic sucrose containing $10^{-4} \mathrm{M}$ TET resulted in the same typical effects of this compound when the 
same concentration was added directly to Warburg vessels (Table 3). However, washing the mitochondria once with $0.25 \mathrm{M}$ sucrose prevented to a great extent the inhibitory actions of TET.

\section{Adenosine triphosphatases}

The actions of TET on liver mitchondrial ATPases are shown in Figs. 1 and 2. Freshly prepared normal mitochondria show very little Mg ATPase activity but this

\section{TABLE 4. DIPHOSPHOPYRIDINE NUCLEOTIDE (DPN) REQUIREMENT FOR TRIETHYLTIN TREATED MITOCHONDRIA}

\begin{tabular}{l|c|c|c|c}
\hline \multirow{2}{*}{$\begin{array}{c}\text { Triethyltin } \\
\text { concentration }\end{array}$} & \multicolumn{2}{|c|}{ Glutamate 0.01 M } & \multicolumn{2}{c|}{$\begin{array}{c}\text { Glutamate 0.01 M } \\
\text { plus DPN 0.001 M }\end{array}$} \\
\cline { 2 - 5 } & $Q_{\mathrm{O}_{2}}$ & $\mathrm{P} / \mathrm{O}$ & $Q_{\mathrm{O}_{2}}$ & $\mathrm{P} / \mathrm{O}$ \\
\hline $\begin{array}{l}\text { None } \\
5 \times 10^{-5} \mathrm{M}\end{array}$ & 6.90 & 2.67 & 7.23 & 2.66 \\
\hline
\end{tabular}

Conditions are same as described in methods except that triethyltin and DPN are added as indicated. Designations for $Q_{O_{2}}$ and $\mathrm{P} / \mathrm{O}$ are the same as in Table 3 .

TABLE 5. EFFECTS OF WASHING MITOCHONDRIA ON THE INIIBITORY ACTION OF TRIETHYLTIN

\begin{tabular}{|c|c|c|c|c|}
\hline \multicolumn{2}{|l|}{ Preparation of mitochondria } & Glutamate & Glutamate $0.01 \mathrm{M}$ & Succinate \\
\hline $\begin{array}{l}\text { (1) Liver homogenized and washed } \\
\text { in } 0.25 \mathrm{M} \text { sucrose plus } 10^{-4} \mathrm{M} \\
\text { TET but final suspension made } \\
\text { in } 0.25 \mathrm{M} \text { sucrose. }\end{array}$ & $\stackrel{Q_{O_{2}}}{\mathrm{P} / \mathrm{O}}$ & $\begin{array}{l}0 \\
0\end{array}$ & $\begin{array}{l}2.74 \\
0.88\end{array}$ & $\begin{array}{l}3.76 \\
0.64\end{array}$ \\
\hline $\begin{array}{l}\text { (2) Liver homogenized in } 0.25 \mathrm{M} \\
\text { sucrose plus } 10^{-4} \mathrm{M} \text { TET but } \\
\text { washed and suspended in } 0 \cdot 25 \\
M \text { sucrose }\end{array}$ & $\underset{\mathrm{P} / \mathrm{O}}{Q_{\mathrm{O}_{2}}}$ & $\begin{array}{l}2.64 \\
3.01\end{array}$ & $\begin{array}{l}3 \cdot 76 \\
2 \cdot 34\end{array}$ & $\begin{array}{l}4.50 \\
1.95\end{array}$ \\
\hline $\begin{array}{l}\text { (3) (Control) Liver homogenized, } \\
\text { washed and suspended in } 0.25 \\
M \text { sucrose. }\end{array}$ & $\frac{Q_{\mathrm{P}}}{\mathrm{P} / \mathrm{O}}$ & $\begin{array}{l}3 \cdot 87 \\
2 \cdot 48\end{array}$ & $\begin{array}{l}4 \cdot 32 \\
2 \cdot 78\end{array}$ & $\begin{array}{l}5.90 \\
2.04\end{array}$ \\
\hline
\end{tabular}

Designations for $Q_{O_{2}}$ and $\mathrm{P} / \mathrm{O}$ are the same as in Table 3 .

enzyme becomes markedly activated following damage to the mitochondria. The DNP ATPase on the other hand shows the reverse properties; it is markedly active in normal mitochondria but absent in damaged mitochondria. TET is capable of inhibiting both the DNP ATPases and the Mg ATPases. The actions on the $\mathrm{Mg}$ ATPase were studied on liver mitochondria from rats treated for $20 \mathrm{hr}$ with carbon tetrachloride $(2.5 \mathrm{ml} / \mathrm{kg}$ orally) or on mitochondria which had been treated with digitoxin $(0.5$ per cent). The spectrum of ATPase activity at different $\mathrm{pH}$ values was essentially the same as that reported by Myers and Slater ${ }^{12}$ and Purvis ${ }^{13}$. The $\mathrm{Mg}$ ATPase spectrum was essentially the same regardless of the manner by which the mitochondria were damaged. The enzymic hydrolysis of ATP at $\mathrm{pH} 6.5$ appeared less. 
sensitive to the actions of TET than that at the higher $\mathrm{pH}$ values. Whether this selectivity was the result of a differential action of TET on the specific ATPase as proposed by Myers and Slater ${ }^{12}$; or whether it resulted from differences in the ionization and subsequent penetration of TET into active mitochondrial enzyme sites is not known at the present time.

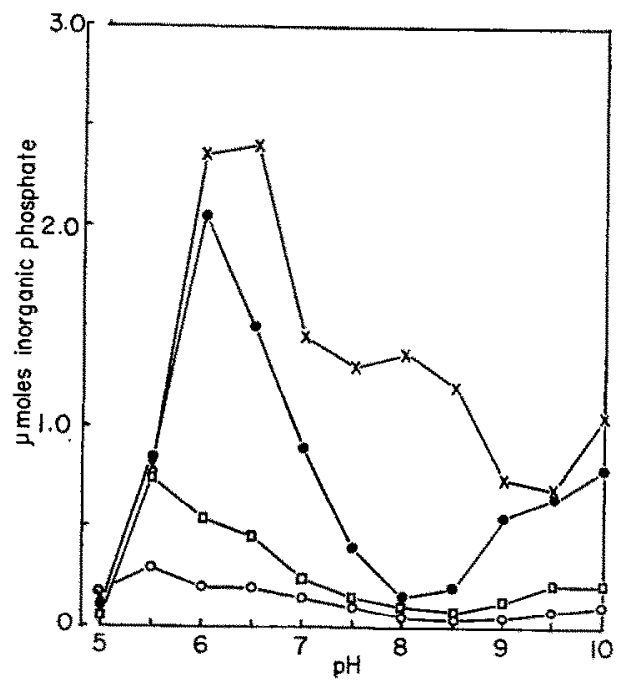

FiG. 1. Effect of triethyltin on the 2:4-dinitrophenol activated adenosinetriphosphatases. Concentrations of triethyltingare: $x-\times$ none, $-10^{-8} \mathrm{M}, \square-\square 10^{-5} \mathrm{M}, \mathrm{O}-\mathrm{O} 10^{-4} \mathrm{M}$.

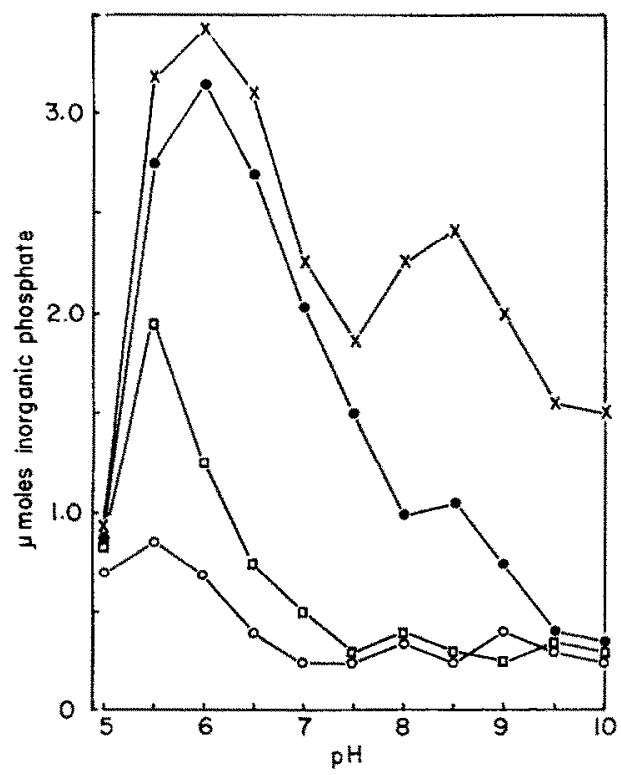

FIG. 2. Effect of triethyltin on the magnesium activated adenosinetriphosphatases. Concentrations of triethyltin are: $x-\times$ none, 
Contrary to the findings of Aldridge ${ }^{4}$ no activation of the latent ATPase by TET could be observed either in vivo or in vitro. Nor was any acceleration of the respiration of mitochondria in an acceptor deficient system noted following in vitro treatment with this compound. TET inhibited the oxygen consumption in the acceptor-deficient, complete phosphorylating and DNP stimulated systems (Table 6).

TABLE 6. EFFECT OF in vitro TRIETHYLTIN ON OXIDATION BY LIVER MITOCHONDRIA IN ACCEPTOR-DEFICIENT SYSTEM

\begin{tabular}{|c|c|c|c|c|}
\hline & & Control & TET $10^{-\mathbf{f}} \mathrm{M}$ & TET $10^{-5} \mathrm{M}$ \\
\hline Experiment no. 1 & $\begin{array}{l}\text { No addition } \\
\text { DNP } 10^{-5} \mathrm{M}\end{array}$ & $\begin{array}{l}1 \cdot 80^{*} \\
2 \cdot 70\end{array}$ & $\begin{array}{l}1.76 \\
2.87\end{array}$ & $\begin{array}{l}1 \cdot 25 \\
2 \cdot 15\end{array}$ \\
\hline Experiment no. 2 & $\begin{array}{l}\text { No addition } \\
\text { hexokinase and glucose }\end{array}$ & $\begin{array}{l}1 \cdot 86 \\
5 \cdot 86\end{array}$ & $\begin{array}{l}1 \cdot 37 \\
5 \cdot 26\end{array}$ & $\begin{array}{l}1 \cdot 13 \\
3 \cdot 39\end{array}$ \\
\hline
\end{tabular}

${ }^{*} Q_{\mathrm{O}_{2}}=\mu \mathrm{AO}_{2} / 10 \mathrm{~min}$.

Conditions are as stated in methods except that hexokinase and glucose are omitted except where indicated. Glutamate $0.01 \mathrm{M}$ is substrate.

\section{DISCUSSION}

Studies with TET have been performed with a view to correlating the in vitro biochemical effects caused by this compound with the toxic actions that it produces in the intact animal. It was found that TET was a potent uncoupler of oxidative phosphorylation in rat liver and brain homogenates and mitochondria but that some of its properties differ from those of other uncouplers, i.e. DNP and thyroxine. The ability of TET to inhibit the respiration of both a complete phosphorylating system and an acceptor-deficient system and its ability to inhibit mitochondrial ATPases differentiate the actions of this compound from that of DNP. Like thyroxine, TET can produce mitochondrial swelling (see subsequent paper) at a concentration lower than that at which it is capable of uncoupling oxidative phosphorylation but unlike classical uncouplers TET produces a fall in the body temperature of rats. ${ }^{14}$

Aldridge ${ }^{4}$ stated that although the activation of an ATPase was not the primary mode of action of TET, the ability of this compound to stimulate oxidation in an acceptor-deficient system paralleled its ability to stimulate the ATPases. We could find no such acceleration of respiration in an acceptor-deficient system by TET. The inhibitory action of TET on the mitochondrial ATPases and the ability of this compound to uncouple oxidative phosphorylation make it similar to the biochemical actions of sodium azide and $p$-hydroxymercuribenzoate. ${ }^{15,16}$ TET, however, appears to be at least ten times more potent than either of these latter two compounds.

Recently, there has been interest in the possibility that the DNP ATPase represents the phosphorylation associated with the diaphorase region of the electron transport system and that the Mg ATPase constitutes a part of the enzymes sequence involved in the DNP ATPase system. ${ }^{16}$ It would appear that TET inhibits some step common to both pathways. TET must also uncouple at the other sites along the electron transport chain since the phosphorylations associated with succinate oxidation are markedly reduced. Because a portion of the TET molecule in solution exists as a 
cation, ${ }^{3}$ it is possible that it could accept electrons along the electron transport chain and thus divert their passage along the chain. The ability to participate in the electron transport chain could also account for the uncoupling ability of TET, since by accepting electrons and thereby setting up an alternate route for electron flow it is possible that such a pathway could exclude a step in the chain normally associated with energyrich phosphate transfer. Aldridge and Cremer, however, could find no effect of TET on enzyme systems of the electron transport chain. ${ }^{3}$

By measuring ATPase activity of liver mitochondria at various hydrogen ion concentrations Myers and Slater ${ }^{12}$ could identify three separate DNP ATPases which they proposed as representative of the enzymes which transferred the high-energy phosphate bonds from the various sites along the electron transport chain. However, more recent work ${ }^{17}$ has revealed that there are no multiple $\mathrm{pH}$ optima for respiratory, phosphorylative and transfer reactions in liver mitochondria but instead only one single broad pH optima exists so that the identification of the various sites of phosphate transfer by this approach is not possible. The decreasing DNP ATPase activity with increasing $\mathrm{pH}$ suggests that the activation by DNP $\left(\mathrm{p} K_{a} 4 \cdot 0\right)$ is associated with the undissociated phenol which decreases in concentration with increasing $\mathrm{pH}$. However, Myers and Slater ${ }^{12}$ feel that the active molecular species of DNP is the ionized form so that changes in $\mathrm{pH}$ affect only the enzyme sites rather than the inhibitor. This view does not consider the effect of $\mathrm{pH}$ upon the penetration of DNP into the mitochondrial sites. With most membranes the undissociated ion passes through with greater ease. Thus the greater activity of the DNP ATPase at the lower $\mathrm{pH}$ values could merely be the result of a greater concentration of DNP available at the active sites within the mitochondria since a greater quantity of the compound exists as the unionized form at these lower $\mathrm{pH}$ values. Likewise, the differential inhibition of the DNP ATPases and the Mg ATPase by TET $\left(\mathrm{p} K_{a} 6.5\right)$ at the various hydrogen ion concentrations may not be the selective inhibition of the ATPases with the higher $\mathrm{pH}$ optimum but merely an index of the penetration of TET into the active sites of the mitchondria since the concentration of the unionized species of TET will increase as the $\mathrm{pH}$ is increased. It is interesting to note that van der Kerk and Luijten ${ }^{18}$ found the fungicidal activity of TET was more pronounced at higher $\mathrm{pH}$ values.

The correlation of biochemical properties of drugs which are observed in vitro with those actions of the drug which are seen in the intact animal is a difficult problem. Since the main action of TET appears to be on the central nervous system ${ }^{2}, 14$ attention should be focused upon the biochemical changes that occur in nervous tissue. It was shown that TET inhibits the respiration of brain slices following in vitro and in vivo administration of the compound whereas it produces only slight inhibition of liver slice respiration in vitro and none in vivo. The exact mechanism of the decreased oxygen uptake by brain slices is not completely understood. It may be due to a loss of cofactors (e.g. DPN) or to an actual interference with the enzymes concerned with electron transport.

Concomitant with the decreased oxygen uptake by brain slices, the coupling of oxidation with high energy phosphate transfer in brain mitochondria and homogenates is disrupted by TET added in titro. The combination of these two actions, i.e. decreased respiration and uncoupled oxidative phosphorylation, could result in a decrease in the energy reserves of the brain which would contribute to the toxicity of this agent. This hypothesis, however, is not strengthened by the findings of Stoner and 
Threlfall ${ }^{19}$ that there is no decrease in high energy phosphate containing compounds in animal tissues following TET administration.

Although a disruption of energy metabolism in the brain could account for many of the toxic actions of TET further study must be undertaken before these two effects of TET can be unequivocally associated.

Acknowledgements-The authors wish to acknowledge the excellent technical assistance of $\mathrm{Mr}$. Richard Bird. These studies were aided by a contract between the Office of Naval Research, Department of the Navy and the University of Michigan, NR 303-439.

\section{REFERENCES}

1. J. M. Barnes and H. B. Stoner, Pharm. Rev. 11, 211 (1959).

2. T. Alajouanine, L. Derobert and S. Thieffrey, Rev. Neurol. 98, 85 (1958).

3. W. N. Aldridge and J. E. Cremer, Biochem. J. 61, 406 (1955).

4. W. N. ALDRIDGE, Biochem. J. 69, 367 (1958).

5. W. Deutsch, J. Physiol. 87, 56P (1936).

6. T. M. Brody and J. A. Bain, Proc. Soc. Exp. Biol., N. Y. 77, 50 (1951).

7. V. R. Potter and C. A. Elvehjem, J. Biol. Chem. 114, 495 (1936).

8. G. H. Hogeboom, W. C. Schneider and G. E. Pallade, J. Biol. Chem. 172, 619 (1948).

9. T. M. Brody and J. A. BaIn, J. Biol. Chem. 195, 685 (1952).

10. C. H. Fiske and Y. SubBaRow, J. Biol. Chem. 66, 375 (1925).

11. J. E. Cremer, Biochem. J. 67, 87 (1957).

12. D. K. Myers and E. C. SLATER, Biochem. J. 67, 558 (1957).

13. J. L. Purvis, Exp. Cell Res. 16, 98 (1959).

14. H. B. Stoner, J. M. BARnes and J. E. Duff, Brit. J. Pharmacol. 10, 16 (1955).

15. D. K. MYers and E. C. SLATER, Biochem. J. 67, 572 (1957).

16. P. Siekevitz, H. Löw, L. Ernster and O. LindBerg, Biochim. Biophys. Acta 29, 378 (1958).

17. B. Chance and H. Conrad, J. Biol. Chem. 234, 1568 (1959).

18. G. J. M. van der Kerk and J. G. A. Luiten, J. Appl. Chem. 4, 314 (1954).

19. H. B. Stoner and C. J. Threlfall, Biochem. J. 69, 376 (1958). 